Jurnal Gizi Klinik Indonesia

Vol. 17 No. 3, Januari 2021 (147-156)

ISSN 1693-900X (Print), ISSN 2502-4140 (Online)

Tersedia online di https://jurnal.ugm.ac.id/jgki

DOI: https://doi.org/10.22146/ijcn.42623

\title{
Korelasi asupan makronutrien dengan indeks massa tubuh, kadar gula darah, dan protein total darah pada pengguna narkoba
}

Correlation of macronutrient intake with body mass index, blood sugar levels, and total blood protein in drug users

\author{
Ginta Siahaan ${ }^{1}$, Tiarlince Bakara ${ }^{1}$, Yusnita ${ }^{1}$, Kasmiyeti ${ }^{2}$
}

${ }^{1}$ Jurusan Gizi, Poltekkes Kemenkes Medan

${ }^{2}$ Jurusan Gizi, Poltekkes Kemenkes Padang

\begin{abstract}
Background: Random blood sugar level and total blood protein need to be measured among drug users because their macronutrient intakes (carbohydrates, fat, protein, and energy) are not appropriate to the pattern of daily habits before uses drugs. Drug users had decreased appetite during the influence and withdrawal symptoms of drugs with the impacts on their body mass index (BMI). Objective: To analyze the correlation of macronutrient intakes between the random blood sugar level, total blood protein, and BMI drug users. Methods: This research was conducted with a cross-sectional design and observational study. 73 drug users were included in the study with the screening by inclusion criteria. 24-hour food recall was used to collect the macronutrient intakes, random blood sugar levels and total blood protein were monitored by the GOD-PAP method, and BMI was measured by weight and height. Data analysis used Pearson's correlation test in bivariate and multivariate was carried out by multiple linear regressions. Results: Pearson's correlation analysis showed that there was a significant correlation between macronutrient intakes (energy, carbohydrate, fat) with random blood sugar level, total blood protein, and BMI. BMI was the most affected by energy $(\beta=0.531)$, random blood sugar level was the most affected by carbohydrates $(\beta=0.073)$, and total blood protein was the most affected by protein $(\beta=0.837)$. Conclusions: Macronutrient intake is significantly related to BMI, random blood sugar levels, and total blood protein in drug users. Community collaboration with related parties such as the public health service and National Narcotics Agency will very quickly detect drug side effects early on eating disorders that will affect the nutritional status of its users.
\end{abstract}

KEYWORDS: blood sugar levels; BMI; drug users; macronutrien; total protein

\begin{abstract}
ABSTRAK
Latar belakang: Pengukuran biokimia darah seperti kadar gula darah sewaktu (GDS) dan protein total darah serta indeks massa tubuh (IMT) pada pengguna narkoba perlu dilakukan karena asupan makronutrien (karbohidrat, lemak, protein, dan energi) sudah tidak sesuai dengan pola kebiasaan sehari-hari seperti sebelum mengonsumsi narkoba. Pengguna narkoba umumnya mengalami penurunan nafsu makan selama masa pengaruh obat dan ketika putus obat (withdrawal symptom) sehingga akan berdampak pada kesehatan. Tujuan: Penelitian ini bertujuan menganalisis hubungan asupan makronutrien dengan GDS, protein total darah, dan IMT pada pengguna narkoba. Metode: Penelitian cross-sectional pada 73 subjek pengguna narkoba yang memenuhi kriteria inklusi. Asupan makronutrien diketahui dengan metode food recall 24 jam, GDS dan protein total darah diperoleh dengan pengambilan darah sampel menggunakan metode GOD-PAP sedangkan IMT berdasarkan pengukuran berat badan dan tinggi badan. Analisis data menggunakan uji korelasi Pearson dan uji regresi linear berganda. Hasil: Asupan makronutrien (energi, karbohidrat, lemak) berhubungan signifikan dengan GDS, protein total darah, dan IMT. Asupan energi paling mempengaruhi IMT $(\beta=0,531)$, karbohidrat paling mempengaruhi GDS $(\beta=0,073)$, dan protein paling mempengaruhi protein total darah $(\beta=0,837)$. Simpulan: Asupan zat gizi makronutrien secara signifikan berpengaruh terhadap IMT, GDS, dan protein total darah pada pengguna narkoba. Kerjasama masyarakat dengan pihak terkait seperti Dinas Kesehatan dan BNN dapat mendeteksi secara dini efek samping narkoba terhadap gangguan makan yang akan berpengaruh terhadap status gizi pengguna narkoba.
\end{abstract}

KATA KUNCI: makronutrien; IMT; GDS; protein total; pengguna narkoba

Korespondensi: Ginta Siahaan, Jurusan Gizi, Poltekkes Kemenkes Medan, Jl. Negara, Simpang Tanjung Garbus, Lubuk Pakam, Medan, Indonesia, e-mail: ginzsiahaan@gmail.com

Cara sitasi: Siahaan G, Bakara T, Yusnita Y, Kasmiyeti K. Korelasi asupan makronutrien dengan indeks massa tubuh, kadar gula darah, dan protein total darah pada pengguna narkoba. Jurnal Gizi Klinik Indonesia. 2021;17(3):147-156. doi: 10.22146/ijcn.42623 


\section{PENDAHULUAN}

NAPZA merupakan singkatan dari narkotika, psikotroprika, dan zat aditif lain (1). Pada masyarakat lebih populer dikenal dengan istilah narkoba yang merupakan pengonsumsian jenis narkotika, obat-obat berbahaya serta alkohol (2). Penyalahgunaan narkoba dari tahun ke tahun meningkat dari $24 \%$ pada tahun 2004 menjadi $28 \%$ pada tahun 2013. Sekitar 16,9 juta orang pada tahun 2008 dan diperkirakan meningkat menjadi 22,3 juta per tahun 2013 penggunaan narkoba terjadi pada pelajar dan mahasiswa menurut Badan Narkotika Nasional (BNN) dan Universitas Indonesia (3). Sementara di Provinsi Sumatera Utara pada tahun 2009 diperkirakan pengguna narkoba mencapai 4,7\% dari jumlah pelajar dan mahasiswa. Bahkan, menurut hasil laporan BNN tahun 2014, Sumatera Utara menduduki peringkat keempat pengguna narkoba terbanyak di Indonesia (4).

Pengguna narkoba umumnya rawan terhadap masalah gizi karena penurunan nafsu makan selama masa pengaruh obat dan ketika putus obat (withdrawal symptoms) yang ditandai dengan gejala kecemasan, kegelisahan, depresi, dan gejala psikis lainnya. Pada keadaan depresi, seseorang cenderung lupa akan pemenuhan kebutuhan dasar, seperti kebutuhan makan, kebersihan diri, dan istirahat. Apabila asupan makanan rendah dan berlangsung dalam jangka waktu yang relatif lama, seseorang akan mengalami defisiensi zat gizi. Hal ini berdampak pada terjadinya penurunan berat badan dan jika berlangsung dalam waktu yang cukup lama akan menyebabkan penggunaan cadangan energi secara terus menerus yang dimulai dari hati, otot, dan selanjutnya terjadi pemecahan jaringan tubuh. Hal tersebut dapat dilihat dari pengukuran indeks massa tubuh (IMT), protein total darah, serta kadar gula darah yang rendah (5-7). Hasil studi sebelumnya melaporkan efek samping penggunaan narkoba pada rendahnya kadar hemoglobin $(\mathrm{Hb})$, yang tampak pada pengguna narkoba jenis sabusabu dan ganja yang mengalami anemia $(28,8 \%)(8)$.

Penurunan berat badan yang terjadi terus menerus bisa disebabkan oleh penurunan nafsu makan akibat efek samping dari jenis narkoba yang digunakan yaitu mual, penyerapan zat gizi terhambat, gangguan gastrointestinal, atau penurunan imunitas tubuh yang menyebabkan penyakit infeksi. Efek samping dari penggunaan narkoba terhadap gangguan metabolisme dan biokimia darah berbeda-beda tergantung jenis narkoba yang dikonsumsi (9). Penggunaan narkoba secara berlebihan dan berkesinambungan dapat menimbulkan peningkatan reactive oxygen species (ROS) yang merupakan radikal bebas. Reactive oxygen species dapat menimbulkan toksik yang merusak sel-sel tubuh termasuk eritrosit, sel hati, dan sel gastrointestinal (10).

Hasil penelitian di Dhaka menunjukkan bahwa narkoba berpengaruh nyata pada penurunan IMT, $\mathrm{Hb}$, protein total, dan kadar albumin, serta sekitar 74\% pengguna narkoba mengalami defisiensi zat gizi (5). American Dietetic Association menyatakan bahwa asupan makronutrien dan energi adalah nutrisi penting yang dibutuhkan tubuh dalam melakukan aktivitas fisik, pemeliharaan tubuh, serta perbaikan otot dan jaringan yang rusak (11). Asupan karbohidrat, protein, dan lemak dalam metabolisme akan menghasilkan energi yang digunakan tubuh untuk aktivitas sehari-hari (12).

Studi sebelumnya pada pecandu narkoba telah membahas pengaruh asupan zat gizi terhadap IMT dan biokimia darah (5). Sementara pada penelitian ini menjabarkan asupan makronutrien terhadap kadar gula darah dan protein total darah yang secara spesifik berpengaruh terhadap penurunan massa otot yang termanifestasi pada IMT. Keunikan lain pada studi ini adalah sampel diambil dari remaja putra pengguna narkoba yang tidak terkonsentrasi di lapas maupun panti rehabilitasi narkoba $(13,14)$ sehingga jika ditinjau dari asupan zat gizi, orang yang terprogram penanggulangan akibat narkoba akan berbeda dengan pengguna narkoba yang masih berada di rumah. Perbedaan lainnya kemungkinan pada tingkat keparahan akibat narkoba dan efeknya terhadap status gizi, proses efek samping juga akan berbeda antara pecandu dan orang yang hanya sebagai pengguna narkoba. Dengan demikian, tujuan penelitian ini adalah menganalisis korelasi asupan makronutrien dengan IMT, kadar gula darah, dan protein total darah pada pengguna narkoba di Medan Tembung. Pemilihan daerah dilakukan atas saran dari BNN Sumatera Utara yang mensinyalir remaja-remaja putra di daerah tersebut terindikasi sebagai pengguna narkoba. 


\section{BAHAN DAN METODE}

\section{Desain dan subjek}

Penelitian ini bersifat observasional dengan desain cross-sectional yang dilaksanakan pada bulan Maret sampai Mei 2016. Penentuan sampel dilakukan dengan dua cara, yaitu purposive sampling dan snowball sampling. Cara purposive dengan kriteria inklusi yaitu sudah menggunakan narkoba lebih dari 6 bulan, berjenis kelamin laki-laki, berusia 15-21 tahun, serta bersedia menjadi subjek penelitian dengan mengisi informed consent. Sementara kriteria eksklusi adalah pengguna narkoba yang pernah direhabilitasi, dalam keadaan sakit, dan masyarakat pendatang atau berdomisili di luar Medan Tembung. Selanjutnya, dilakukan teknik snowball sampling yaitu informasi diperoleh dari satu informan ke informan selanjutnya sehingga diharapkan hadir di tempat pengambilan darah. Berdasarkan kedua teknik kombinasi pengambilan sampel tersebut, maka diperoleh subjek sebanyak 73 orang pengguna narkoba. Pengumpulan data dilakukan peneliti dengan dibantu oleh empat orang enumerator yang berasal dari mahasiswa Jurusan Gizi semester VIII yang terlebih dahulu diberikan briefing selama dua hari untuk menyamakan persepsi. Penelitian ini telah memperoleh rekomendasi keabsahan dari Komite Etik Fakultas Kedokteran Universitas Sumatera Utara dengan nomor: 507/TGL/KEPK FK USU-RSUP $\mathrm{HAM} / 2016$.

\section{Pengumpulan dan pengukuran data}

Asupan makronutrien. Data asupan makronutrien (energi, karbohidrat, protein, dan lemak) dikumpulkan dengan melakukan food recall 24 jam selama tiga hari tidak berturut-turut, kemudian data asupan makan diolah menggunakan program Nutrisurvey.

Indeks massa tubuh (IMT). Data IMT diperoleh dengan cara mengukur berat badan menggunakan timbangan digital merek Camry dengan ketelitian $0,01 \mathrm{~kg}$ dan tinggi badan menggunakan microtoice dengan ketelitian $0,1 \mathrm{~cm}$. Indeks massa tubuh dihitung berdasarkan rumus berat badan $(\mathrm{kg})$ dibagi dengan kuadrat tinggi badan (m).

Glukosa darah sewaktu (GDS). Data GDS diperoleh dengan melakukan pengambilan darah sebanyak 2 cc pada pembuluh darah lengan sebelah kiri. Kadar GDS pengguna narkoba diperiksa dengan metode Glucose Oxsidase - Peroxidase Aminoantypirin (GODPAP) menggunakan alat LOT D393 Biocon Jerman. Metode GOD-PAP merupakan metode mengukur kadar glukosa setelah dioksidasi secara enzimatis menggunakan enzim glukosa oksidase (GOD). Pengambilan darah dilakukan oleh tenaga analis kesehatan selanjutnya diperiksa di Laboratorium Kesehatan Daerah (Labkesda) Sumatera Utara.

Protein total darah. Data protein total juga diperoleh dengan melakukan pengambilan darah sebanyak 2 cc pada pembuluh darah lengan sebelah kiri. Pemeriksaan protein total dilakukan dengan menggunakan metode biuret memakai alat spektrofotometri. Pengambilan darah dilakukan oleh tenaga analis kesehatan selanjutnya diperiksa di Laboratorium Kesehatan Daerah (Labkesda) Sumatera Utara.

\section{Analisis data}

Analisis univariat untuk menggambarkan masingmasing variabel yang disajikan dalam tabel distribusi frekuensi. Analisis bivariat menggunakan uji korelasi Pearson untuk data yang terdistribusi normal berdasarkan uji Kolmogrov-Smirnov. Sementara data yang tidak terdistribusi normal, dianalisis menggunakan uji korelasi Rank Spearman. Analisis multivariat dilakukan untuk mengetahui variabel bebas yang paling berpengaruh terhadap variabel terikat dengan uji statistik regresi linier.

\section{HASIL}

\section{Karakteristik subjek}

Sebagian besar subjek berumur 19-21 tahun $(60,27 \%)$ dan berpendidikan terakhir perguruan tinggi $(41,10 \%)$. Jenis narkoba yang paling banyak digunakan adalah sabu-sabu $(30,14 \%)$ serta kombinasi sabu-sabu dan ganja (41,84\%). Mayoritas subjek menggunakan narkoba kurang dari 12 bulan (35,61\%) (Tabel 1). Hasil wawancara menggunakan metode food recall tiga hari tidak berturut-turut diperoleh rerata asupan makronutrien pada pengguna narkoba masih di bawah angka kecukupan gizi (AKG) 2013. Demikian juga dengan rerata kadar biokimia darah yang masih di bawah standar yaitu GDS 
91,63 mg/dL dan kadar protein total sebesar 5,86 mg/dL. Namun, rerata IMT subjek masih berada pada kisaran status gizi normal yaitu $20,92 \mathrm{~kg} / \mathrm{m}^{2}$ (Tabel 2).

\section{Korelasi asupan makronutrien dengan IMT, GDS,} dan protein total darah

Hasil uji korelasi Pearson menunjukkan hubungan yang signifikan antara asupan makronutrien dengan IMT, GDS, dan protein total darah pada pengguna narkoba. Asupan energi memiliki korelasi signifikan $(p=0,006)$ dengan keeratan hubungan yang paling kuat dengan IMT ( $r=0,519)$. Asupan karbohidrat memliki korelasi signifikan $(\mathrm{p}=0,001)$ dengan keeratan hubungan yang paling kuat dengan kadar GDS $(r=0,505)$. Asupan protein memliki korelasi signifikan $(\mathrm{p}=0,001)$ dengan keeratan hubungan yang paling kuat $(\mathrm{r}=0,804)$ dengan kadar protein total darah. Sementara asupan lemak juga

Tabel 1. Karakteristik subjek

\begin{tabular}{llrr}
\hline Variabel & Kategori & n & \% \\
\hline Umur (tahun) & $15-18$ & 29 & 39,73 \\
Pendidikan & $19-21$ & 44 & 60,27 \\
& SD & 9 & 12,34 \\
& SMP & 16 & 22,92 \\
& SMA & 18 & 24,65 \\
Lama penggunaan & Perguruan tinggi & 30 & 41,10 \\
(bulan) & $<12$ & 26 & 35,61 \\
& & 24 & 32,87 \\
Jenis narkoba & S-24 & 23 & 31,52 \\
& $>24$ & 22 & 30,14 \\
& Sabu-sabu & 12 & 16,43 \\
& Sabu-sabu dan lem & 31 & 41,47 \\
& Sabu-sabu dan ganja & 7 & 8,59 \\
& Sabu-sabu dan ectasy & 1 & 1,37 \\
\hline
\end{tabular}

memiliki korelasi signifikan dengan IMT, GDS, dan protein total darah, tetapi dengan keeratan hubungan sedang (Tabel 3).

\section{Analisis multivariat asupan makronutrien terhadap IMT}

Hasil regresi linier berganda pada Tabel 4 menunjukkan bahwa asupan energi paling berpengaruh terhadap IMT. Pada penelitian ini nilai koefisien asupan energi sebesar 0,192 akan menghasilkan konstanta IMT sebesar $7,095 \mathrm{~kg} / \mathrm{m}^{2}$ artinya asupan energi akan mempengaruhi peningkatan IMT sebesar 7,095 kali dibandingkan asupan makronutrien lain.

\section{Analisis multivariat asupan makronutrien terhadap GDS}

Selanjutnya, hasil regresi linier berganda menunjukkan bahwa asupan karbohidrat paling berpengaruh terhadap GDS. Pada penelitian ini nilai koefisien asupan karbohidrat sebesar 0,403 akan menghasilkan konstanta GDS sebesar 12,197 mg/ dl artinya asupan karbohidrat akan mempengaruhi peningkatan GDS sebesar 12,197 kali dibandingkan asupan makronutrien lain (Tabel 5).

Tabel 3. Analisis korelasi asupan makronutrien dengan IMT, GDS, dan protein total

\begin{tabular}{lcccccc}
\hline \multirow{2}{*}{$\begin{array}{c}\text { Asupan } \\
\text { makronutrien }\end{array}$} & \multicolumn{2}{c}{ IMT } & \multicolumn{2}{c}{ GDS } & \multicolumn{2}{c}{ Protein total } \\
\cline { 2 - 7 } & $\mathbf{r}$ & $\mathbf{p}$ & $\mathbf{r}$ & $\mathbf{p}$ & $\mathbf{r}$ & $\mathbf{p}$ \\
\hline Energi & 0,519 & 0,006 & 0,410 & 0,001 & 0,520 & 0,001 \\
Karbohidrat & 0,429 & 0,001 & 0,505 & 0,001 & 0,204 & 0,045 \\
Protein & 0,370 & 0,001 & 0,074 & 0,033 & 0,804 & 0,001 \\
Lemak & 0,390 & 0,001 & 0,257 & 0,028 & 0,355 & 0,028 \\
\hline
\end{tabular}

Tabel 2. Rerata asupan makronutrien, IMT, GDS, dan protein total darah

\begin{tabular}{lrrrr}
\hline Asupan & Minimal & Maksimal & Rerata & SD \\
\hline Energi (kkal) & $1.074,10$ & $2.395,60$ & $1.851,59$ & 355,40 \\
Karbohidrat (g) & 99,30 & 487,60 & 239,57 & 97,44 \\
Protein $(\mathrm{g})$ & 1,98 & 71,86 & 53,26 & 10,72 \\
Lemak $(\mathrm{g})$ & 24,70 & 88,43 & 48,18 & 13,82 \\
GDS $(\mathrm{mg} / \mathrm{dL})$ & 62,00 & 156,00 & 91,63 & 20,97 \\
Protein total $(\mathrm{mg} / \mathrm{dl})$ & 2,78 & 7,41 & 5,86 & 1,68 \\
IMT $\left(\mathrm{kg} / \mathrm{m}^{2}\right)$ & 16,60 & 27,50 & 20,92 & 2,78 \\
\hline
\end{tabular}

$\mathrm{SD}=$ standar deviasi; GDS = glukosa darah sewaktu; IMT = indeks massa tubuh 
Tabel 4. Hasil analisis multivariat asupan makronutrien terhadap IMT

\begin{tabular}{lccccr}
\hline \multicolumn{1}{c}{ Variabel } & B & SD & Beta & Rho(P) & $\mathbf{R}^{2}$ \\
\hline Konstanta & 7,095 & 1,787 & & 0,000 & 0,332 \\
Asupan energi & 0,192 & 0,001 & 0,470 & 0,692 & \\
Asupan karbohidrat & 0,003 & 0,004 & 0,120 & 0,378 & \\
Asupan protein & 0,025 & 0,031 & 0,097 & 0,420 & \\
Asupan lemak & 0,083 & 0,029 & 0,576 & 0,006 & \\
\hline
\end{tabular}

Tabel 5. Hasil analisis multivariat asupan makronutrien terhadap GDS

\begin{tabular}{lccccr}
\hline \multicolumn{1}{c}{ Variabel } & B & SD & Beta & Rho(P) & $\mathbf{R}^{2}$ \\
\hline Konstanta & 12,197 & 1,787 & & 0,000 & 0,380 \\
Asupan energi & 0,034 & 0,017 & 0,433 & 0,046 & \\
Asupan karbohidrat & 0,403 & 0,229 & 0,879 & 0,001 & \\
Asupan protein & 0,228 & 0,082 & 0,299 & 0,049 & \\
Asupan lemak & 0,389 & 0,116 & 0,424 & 0,042 & \\
\hline
\end{tabular}

Tabel 6. Hasil analisis multivariat asupan makronutrien terhadap kadar protein total darah

\begin{tabular}{lccccr}
\hline \multicolumn{1}{c}{ Variabel } & B & SD & Beta & Rho(P) & $\mathbf{R}^{2}$ \\
\hline Konstanta & 4,554 & 0,625 & & 0,065 & 0,586 \\
Asupan energi & 0,531 & 0,532 & 0,450 & 0,004 & \\
Asupan karbohidrat & 0,073 & 0,044 & 0,120 & 0,361 & \\
Asupan protein & 0,837 & 0,820 & 0,615 & 0,001 & \\
Asupan lemak & 0,183 & 0,089 & 0,676 & 0,048 & \\
\hline
\end{tabular}

\section{Analisis multivariat asupan makronutrien terhadap kadar protein total darah}

Hasil regresi linier berganda pada Tabel 6 menunjukkan bahwa asupan protein paling berpengaruh terhadap kadar protein total darah. Pada penelitian ini nilai koefisien asupan protein sebesar 0,837 akan menghasilkan konstanta IMT sebesar 4,554 mg/dl. Artinya, asupan protein akan mempengaruhi peningkatan kadar protein total darah sebesar 4,554 kali dibandingkan asupan makronutrien lain seperti energi, karbohidrat dan lemak.

\section{BAHASAN}

\section{Karakteristik subjek}

Hasil penelitian ini menunjukkan bahwa kelompok umur 19-21 tahun yang paling banyak menjadi pengguna narkoba. Hal ini sesuai dengan hasil survei sebelumnya yang menyatakan bahwa dari empat belas panti rehabilitasi di Jakarta, jumlah pengguna alkohol, rokok, dan zat adiktif yang terbesar ditemukan pada kelompok umur 15-24 tahun. Golongan umur dewasa muda tersebut cenderung menampilkan perilaku yang memberi kepuasan dan memenuhi kebutuhan sosial serta psikologis dengan mengonsumsi narkoba (15). Pada golongan usia ini, masih proses mencari jadi diri dan sangat mudah terpengaruh oleh lingkungan sehingga mudah terjerumus ke dunia kriminal termasuk penggunaan narkoba (16).

Mayoritas tingkat pendidikan akhir pengguna narkoba adalah perguruan tinggi dan terendah adalah tingkat sekolah dasar. Hal ini sejalan dengan studi terdahulu yang menyatakan bahwa pengguna narkoba terbanyak dimulai pada jenjang pendidikan sekolah menengah hingga perguruan tinggi (17). Jenjang pendidikan perguruan tinggi merupakan presentase terbesar karena umumnya pengguna narkoba merupakan anak indekos dan menempuh pendidikan di lokasi yang berbeda dengan orang tua sehingga jauh dari pengawasan orang tua. Hasil ini diperkuat oleh hasil penelitian yang menyatakan bahwa sebagian besar pengguna narkoba yang menjadi subjek penelitian tidak tinggal bersama dengan orang tua $(62,1 \%)(18)$.

Penelitian ini menemukan bahwa jenis narkoba yang paling banyak digunakan subjek adalah sabu-sabu, 
diikuti kombinasi sabu-sabu dan ganja kemudian hanya menggunakan sabu-sabu. Sabu-sabu merupakan jenis narkoba yang paling diminati para pengguna narkoba karena lebih mudah didapat dan peredarannya lebih banyak ditemukan di lingkungan masyarakat. Selain itu, sabu-sabu dapat memberikan respon yang lebih cepat bagi para pengguna seperti euforia berlebihan, sangat percaya diri serta merasa fit lebih dari 24 jam (2). Pemakaian narkoba jenis sabu-sabu meningkat tajam seiring dengan semakin mudah ketersediaanya di negara Iran (19). Sementara di Indonesia, pemakain sabu-sabu meningkat tajam sejak tahun 2012 sampai 2016 yang tercatat sebagai kasus kriminalitas dan berhasil diungkap sebanyak 1.867 dan diikuti ganja 128 kasus (20).

Penelitian ini juga menemukan bahwa lama penggunaan narkoba yang terbesar berada pada rentang waktu kurang dari 12 bulan. Berdasarkan hasil wawancara in-depth interview, persentase terkecil terdapat pada lama penggunaan lebih dari 24 bulan karena pengguna narkoba mulai merasakan efek secara permanen dari narkoba dan pemakaiannya dapat berlanjut secara kontinu. Lama penggunaan narkoba lebih dari 24 bulan akan menunjukkan perubahan fisiologis maupun psikis yang selanjutnya akan mempengaruhi pola-pola kehidupan pengguna narkoba seperti mencuri, suka berbohong, apatis, jarang pulang kerumah serta melakukan tindakan kriminal (21). Sementara itu, persentase paling banyak penggunaan narkoba dengan durasi kurang dari 12 bulan karena pengguna berada pada masa coba-coba. Hal lain yang ditemukan akibat konsumsi narkoba terlalu lama dapat menurunkan respon imunitas dalam tubuh sehingga pengguna narkoba mudah terserang penyakit. Pengguna narkoba akan mengalami anoreksia (mual dan muntah) sehingga asupan zat gizi menjadi rendah. Gejala dan efek samping akibat narkoba ini akan berpengaruh terhadap kondisi fisik yang terlihat kurus dan beberapa pemeriksaan biokimia darah termasuk kadar protein total serta albumin darah $(2,5)$.

Lebih lanjut, diperoleh rerata asupan zat gizi makronutrien yaitu energi, karbohidrat, protein, dan lemak yang masih di bawah standar AKG 2013 (22). Sejalan dengan studi sebelumnya bahwa pengguna narkoba di lapas anak pria di Tangerang masih di bawah AKG yang dianjurkan (13). Namun demikian, rerata
IMT pengguna narkoba pada penelitian ini berada pada kategori normal. Hal ini mungkin disebabkan subjek dalam penelitian ini masih dalam taraf pengguna, belum menjadi pecandu. Jika dihubungkan dengan karakteriristik lama menggunakan narkoba, terlihat sebesar $68,48 \%$ subjek adalah pengguna narkoba kurang dari 24 bulan. Hasil ini sejalan dengan studi lain yang melaporkan bahwa hanya sebesar $21,8 \%$ yang mengalami underweight sedangkan bagi pengguna narkoba yang sudah mengalami kecanduan akan memiliki status gizi buruk berdasarkan kategori IMT (23). Hasil biokimia darah yaitu GDS menunjukkan rerata sebesar 93,61 mg/dl yang menandakan bahwa kadar glukosa darah pengguna narkoba berada pada kadar di bawah normal karena GDS sebaiknya berada pada kisaran 110 - 200 mg/dl (24,25). Demikian juga dengan rerata kadar protein total darah yang masih di bawah standar normal yaitu di bawah 6,4 $\mathrm{mg} / \mathrm{dl}$ (26). Hasil penelitian ini sejalan dengan penelitian yang dilakukan pada pengguna narkoba di Bangladesh (5).

\section{Korelasi asupan makronutrien dengan IMT}

Hasil penelitian ini menunjukkan hubungan signifikan antara asupan makronutrien (energi, karbohidrat, protein, lemak) dan IMT dengan tingkat keeratan hubungan paling kuat pada asupan energi $(\mathrm{r}=0,519)$. Hanya sekitar $49,3 \%$ pengguna narkoba pada penelitian ini yang mempunyai IMT dengan kategori normal diikuti kategori kurus (34\%). Hasil studi sebelumnya melaporkan bahwa $74 \%$ pengguna narkoba mengalami defisiensi gizi akibat asupan energi yang rendah (5). Asupan gizi yang adekuat dibutuhkan untuk proses detoksifikasi efek samping dari narkoba dan meningkatkan status gizi. Penelitian lain juga menunjukkan hubungan signifikan antara asupan energi dengan nilai IMT (27). Kekurangan asupan energi mengakibatkan pemecahan lemak tubuh pada jaringan otot dan jaringan adiposa sehingga menyebabkan penurunan nilai IMT yang bermanifestasi pada status gizi pengguna narkoba yang cenderung normal mengarah ke status gizi kurang. Apabila cadangan glikogen dipakai secara terus menerus untuk memenuhi kebutuhan energi, maka dapat menurunkan berat badan yang terlihat dari hasil pengukuran IMT $(7,28)$. 
Lebih lanjut, protein berfungsi meningkatkan antibodi serta mengganti sel-sel yang rusak akibat mengonsumsi narkoba. Salah satu efek samping dari mengonsumsi narkoba adalah penurunan imunitas sehingga pengguna narkoba mudah menderita sakit (23). Apabila asupan karbohidrat dan lemak kurang, maka protein akan dipecah untuk memenuhi kebutuhan energi sehingga fungsi protein dalam proses sintesis jaringan baru akan berkurang dan menyebabkan penurunan IMT (29). Manifestasi klinisnya tampak pada status gizi yang terlihat kurus. Menurut studi sebelumnya, tingkat keparahan penggunaan narkoba berhubungan erat dengan kejadian malnutrisi (14).

Sementara itu, lemak merupakan zat gizi yang menyumbangkan energi paling besar ( $9 \mathrm{kkal}$ ) dan sangat dibutuhkan tubuh sebagai dasar pembuatan membran sel dan pembentukan jaringan adiposa (7). Cadangan lemak akan dipecah untuk diubah menjadi energi jika asupan zat gizi yang dikonsumsi sehari-hari kurang. Lemak memiliki tugas utama sebagai simpanan energi dalam bentuk trigliserida dan memobilisasi energi melalui proses lipolisis sebagai respons terhadap kekurangan energi, lemak kemudian diubah menjadi asam lemak bebas untuk menghasilkan energi (30). Simpanan lemak dalam otot yang dipecah akan berpengaruh pada kehilangan jaringan adiposa yang mengakibatkan penurunan berat badan yang dapat diukur melalui IMT (31).

Hasil analisis multivariat menunjukkan bahwa asupan makronutrien (energi, karbohidrat, protein, dan lemak) mempunyai korelasi terhadap IMT dan ditemukan asupan energi yang paling berpengaruh. Pada penelitian ini koefisien asupan energi sebesar 0,193 akan menghasilkan konstanta IMT sebesar 7,095. Asupan energi akan mempengaruhi peningkatan IMT sebesar 7 kali dibandingkan asupan makronutrien lain. Energi merupakan hasil proses metabolisme karbohidrat, lemak, dan protein. Asupan yang rendah dari karbohidrat, lemak, dan protein akan mempengaruhi keseimbangan energi. Apabila tidak terjadi kecukupan energi dalam tubuh, maka sumber cadangan di dalam tubuh seperti glikogen, lemak di jaringan adiposa, serta jaringan tubuh akan dipecah untuk tetap menghasilkan energi sebagai sumber tenaga (6). Terjadinya ketidakseimbangan energi dalam tubuh merupakan efek samping dari pemakaian narkoba yang dibarengi konsumsi rokok serta sesekali menggunakan zat aditif lainnya seperti alkohol dan lem yang dapat menurunkan nafsu makan (8). Nafsu makan yang rendah akan menyebabkan asupan zat gizi yang masuk ke dalam tubuh menjadi berkurang dan akibatnya pasokan energi juga akan sangat kurang. Asupan zat gizi yang tidak sesuai kebutuhan akan menyebabkan beberapa komponen tubuh yang berfungsi sebagai cadangan akan dipakai untuk menghasilkan energi (32).

\section{Korelasi asupan makronutrien dengan kadar GDS}

Hasil penelitian menunjukkan hubungan signifikan antara asupan makronutrien (energi, karbohidrat, protein, lemak) dengan nilai GDS. Tingkat keeratan hubungan paling kuat ditemukan pada asupan karbohidrat $(\mathrm{r}=0,505)$. Hal ini menunjukkan bahwa semakin rendah asupan zat gizi makro, maka semakin rendah kadar GDS seseorang atau sebaliknya. Hal ini didukung data GDS pengguna narkoba yaitu sekitar $66 \%$ subjek mempunyai GDS dalam kategori tidak normal.

Energi merupakan hasil metabolisme dari zat gizi karbohidrat, lemak, maupun protein. Proses metabolisme yang terjadi bisa melalui proses glikolisis atau glukoneogenesis. Jenis narkotika seperti amphetamine sebagai bahan dasar sabu-sabu serta rokok yang biasa digunakan bersamaan dengan pemakaian ganja dapat menyebabkan kehilangan nafsu makan. Kehilangan keinginan makan akan menyebabkan rendahnya asupan energi (13) sehingga berdampak pada penurunan atau rendahnya kadar GDS pengguna narkoba (7). Hal ini sejalan dengan studi lain yang menyatakan hubungan signifikan antara asupan energi dengan GDS, asupan energi yang diperoleh dari karbohidrat, lemak, dan protein akan turut mempengaruhi proses pembentukan GDS (27).

Karbohidrat merupakan zat gizi makronutrien yang memberikan kontribusi tehadap kadar glukosa dalam darah. Proses metabolisme karbohidrat akan menghasilkan glukosa sebagai sumber energi untuk sel-sel dan jaringan tubuh. Sementara protein terdiri dari beberapa asam amino yang berfungsi sebagai alat bantu transportasi glukosa sehingga jika asupan protein terpenuhi, maka GDS pengguna narkoba berada dalam kisaran normal. Hasil studi menegaskan bahwa pemberian karbohidrat yang tinggi pada hewan coba dapat meningkatkan GDS 
maupun gula darah puasa (GDP) (33). Lebih lanjut, hasil studi sebelumnya menyimpulkan bahwa konsumsi protein lebih bertanggungjawab terhadap berat badan (excess weight) daripada aspek gizi lainnya seperti GDS (34). Namun, hasil studi lain menyatakan bahwa GDS secara nyata dipengaruhi oleh metabolisme karbohidrat dan protein pada otot rangka. Ketersediaan protein akan mempermudah kerja hormon insulin dalam melakukan penyerapan glukosa dan asam amino ke dalam otot rangka dan hati melalui proses glikogenesis (35).

Asupan makronutrien lemak juga berkorelasi positif dengan kadar GDS pengguna narkoba. Hal ini didukung oleh studi yang melaporkan bahwa asam lemak bebas ikut berkontribusi meningkatkan glukosa darah dengan menurunkan penggunaan glukosa dari otot yang terstimulasi insulin (30). Asupan lemak yang dikonsumsi dapat mempengaruhi resistensi insulin dengan mengubah fluiditas membran dan fungsi reseptor yang menghubungkan reseptor insulin dengan insulin sehingga dapat mempengaruhi glukosa darah (27).

Lebih lanjut, hasil uji multivariat menunjukkan bahwa seluruh asupan makronutrien (energi, karbohidrat, protein, dan lemak) berkorelasi terhadap kadar GDS dan ditemukan asupan karbohidrat yang paling berpengaruh. Asupan karbohidrat akan mempengaruhi peningkatan GDS 12 kali lebih besar dibandingkan asupan makronutrien lain. Menurut hasil in-depht interview, subjek menyatakan bahwa sering minum alkohol pada saat di kafe ataupun tempat hiburan malam. Pengguna narkoba juga identik dengan perokok aktif. Alkohol dan rokok dapat memperlambat laju penyerapan zat gizi. Selain itu, berdasarkan hasil recall 24 jam, subjek mengonsumsi makanan dalam jumlah besar, tetapi dengan frekuensi hanya satu kali dalam dua hari. Hal ini karena efek samping narkoba jenis tertentu yang membuat pengguna mengalami penurunan nafsu makan. Konsumsi alkohol dalam jumlah banyak disertai narkoba juga dapat memperlambat laju penyerapan makanan (36). Narkoba yang dikonsumsi oleh remaja dapat mengurangi nafsu makan, penyempitan pembuluh darah jantung, dan iritasi saluran cerna sehingga mengganggu proses penyerapan. Hal ini dapat menyebabkan gangguan penyerapan zat-zat gizi diantaranya karbohidrat yang mengakibatkan GDS menjadi rendah (37).

\section{Korelasi asupan makronutrien dengan kadar protein total darah}

Hasil penelitian menunjukkan hubungan signifikan antara asupan makronutrien (energi, karbohidrat, protein, lemak) dengan kadar protein total darah dan asupan protein menunjukkan tingkat keeratan hubungan paling kuat $(\mathrm{r}=0,804)$. Hal ini menunjukkan bahwa semakin rendah asupan zat gizi makro, semakin rendah kadar protein total darah seseorang dan sebaliknya. Hal ini didukung data protein total darah pengguna narkoba yang hanya sekitar $46 \%$ subjek tergolong dalam kategori normal.

Asupan energi yang sesuai atau mendekati angka kecukupan, akan berdampak terhadap hasil biokimia darah yaitu kadar protein total menjadi normal. Energi yang dihasilkan merupakan cerminan dari terpenuhinya kebutuhan zat gizi makro dengan baik. Pada penelitian ini ditemukan korelasi yang positif antara asupan energi dengan protein total, semakin sedikit energi yang dikonsumsi, terlihat hasil protein total darahnya semakin di bawah normal (30). Hal ini sejalan dengan studi di Bangladesh yang menemukan kadar protein total pengguna narkoba cenderung tidak normal dengan asupan energi yang tidak sesuai dengan kebutuhan (5).

Asupan karbohidrat dan lemak pada pengguna narkoba sangat kurang, hal ini disebabkan gangguan rasa lapar akibat beberapa produk narkoba seperti sabu-sabu yang dapat membuat pengguna tidak merasa lapar dalam jangaka waktu 2-3 hari (2). Sementara ganja, sering digunakan bersamaan dengan konsumsi rokok, efek nikotin ternyata juga dapat menyebabkan rasa mual sehingga asupan karbohidrat dan lemak menjadi rendah. Keadaan ini akan memperparah keadaan protein total di dalam darah, yang merupakan salah satu biomarker terjadinya kekurangan gizi akibat konsumsi zat gizi yang buruk (5). Lebih lanjut, kelebihan konsumsi narkoba dapat mengakibatkan gangguan fungsi sebagai pusat metabolisme tubuh. Narkoba juga dapat mengakibatkan zat gizi tidak dapat tercerna dan terserap dengan baik. Zat gizi protein yang seharusnya dapat menanggulangi kedaan ini, karena jumlah yang dikonsumsi juga rendah akan berdampak terhadap penurunan kadar protein total $(3,5)$.

Hasil uji multivariat menunjukkan seluruh asupan makronutrien (energi, karbohidrat, protein, dan lemak) 
berkorelasi dengan kadar protein total dan asupan protein yang paling berpengaruh. Asupan protein akan mempengaruhi peningkatan protein total sebesar 4,5 kali dibandingkan asupan makronutrien lain. Hasil recall 3 x 24 jam menunjukkan bahwa para pengguna narkoba jarang mengonsumsi lauk hewani sebagai sumber protein, tetapi lebih sering mengonsumsi protein yang berasal dari tahu dan tempe. Protein nabati mempunyai nilai cerna serta kandungan protein yang lebih rendah dibandingkan protein hewani. Selain itu, pengguna narkoba juga identik dengan perokok aktif dan alkohol. Alkohol dapat merusak mukosa pada saluran cerna dan nikotin pada rokok memperlambat laju penyerapan zat gizi. Kondisi tersebut merupakan salah satu penyebab terganggunya pembentukan protein total dan penurunan kadar protein total pada pengguna narkoba $(10,37)$. Hasil studi tentang kualitas protein dalam bahan makanan menemukan bahwa asupan nitrogen yang rendah berkorelasi dengan penurunan kadar protein total diantaranya kadar albumin darah (38).

Penelitian ini menunjukkan bahwa efek mengonsusmi narkoba akan mempengaruhi asupan zat gizi dan berdampak malnutrisi bagi penggunanya. Namun, penelitian mempunyai kelemahan yaitu belum bisa mengambarkan masalah gizi yang lebih spesifik karena beberapa pemeriksaan biokima lainnya belum dilakukan seperti pemeriksaan kadar $\mathrm{Hb}$ darah, ferritin, albumin plasma, respon imunitas, dan antropometri lingkar lengan atas (LILA) yang dapat menjadi indikator rendahnya asupan zat gizi yang berlangsung lama.

\section{SIMPULAN DAN SARAN}

Asupan zat gizi makronutrien berpengaruh signifikan terhadap IMT, GDS, dan kadar protein total darah pada pengguna narkoba. Hasil uji multivariat menunjukkan energi paling berpengaruh terhadap IMT, asupan karbohidrat terhadap GDS, dan asupan protein terhadap kadar protein total darah. Kerjasama masyarakat dengan pihak terkait seperti Dinas Kesehatan dan BNN akan sangat cepat mendeteksi secara dini efek samping narkoba terhadap gangguan makan yang akan berpengaruh terhadap status gizi pengguna narkoba.

\section{Pernyataan konflik kepentingan}

Penulis menyatakan tidak ada konflik kepentingan dalam penelitian ini.

\section{RUJUKAN}

1. Azmiyati SR. Gambaran penggunaan NAPZA pada anak jalanan di Kota Semarang. Jurnal Kesehatan Masyarakat. 2014;9(2):137-43.

2. Badan Narkotika Nasional (BNN). Laporan akhir survei nasional perkembangan penyalahgunaan narkoba tahun anggaran 2014. [series online] 2015 [cited Okt 2018]. Available from: URL: https://bnn.go.id/laporan-akhirsurvei-nasional-perkembangan-penyalahguna-narkobatahun-anggaran-2014/

3. Kementerian Kesehatan RI. Narkoba dapat dicegah dan dapat direhabilitasi. [series online] 2014 [cited Okt 2018. Available from: URL: https://pusdatin.kemkes.go.id/download. php?file=download/pusdatin/buletin/buletin-napza.pdf

4. Badan Narkotika Nasional (BNN). Data tindak pidana narkoba tahun 2007-2011. [series online] 2012 [cited Okt 2018]. Available from: URL: http://www.bnn.go.id

5. Islam SKN, Hossain KJ, Afsaruddin A, Ahsan M. Nutritional status of drug addicts undergoing detoxification: prevalence of malnutrition and influence of illicit durgs and lifestyle. Br J Nutr. 2002;88(5):507-13. doi: 10.1079/ BJN2002702

6. Dalimunthe AN. Gambaran pola konsumsi pangan dan status gizi pada pecandu narkoba di Panti Sosial Parmadi Putra Insyaf Sumatera Utara tahun 2014 [Skripsi]. Medan: FKM Universitas Sumatera Utara; 2014.

7. Almatsier S. Prinsip dasar ilmu gizi. Jakarta: PT. Gramedia Pustaka Utama; 2016.

8. Ginta S, Siallagan RF, Purba R, Oppusungu R. Mikronutrien penyebab anemia pada pengguna narkoba di Medan Tembung. Media Gizi Indonesia. 2018;13(2):89-99. doi: 10.20473/mgi.v13i2.183-193

9. Nasution Z. Menyelamatkan keluarga Indonesia dari bahaya narkoba. Bandung: Citrapustaka Media; 2014.

10. Fitria F, Trisndhini RINKR, Mangimbulude JC, Karwur FF. Merokok dan oksidasi DNA. Sains Medika. 2013;5(2):11320.

11. American Dietetic Association, Dietitians of Canada, American College of Sports Medicine, Rodriguez NR, Marco NMD, Langley S. American College of Sports Medicine stand. Nutrition and athletic performance. Med Sci Sports Exerc. 2009;41(3):709-31. doi: 10.1249/ MSS.0b013e31890eb86

12. Astuti NH. Merokok pintu masuk untuk penyalahgunaan narkoba jenis ganja. Arsip Kesehatan Masyarakat. 2016;(1):45-54. 
13. Wahyuningsih U, Ali K, Ekawidyani KR. Asupan zat gizi dan status anemia pada remaja laki-laki pengguna narkoba di lembaga permasyarakatan anak pria Tangerang. Jurnal Gizi dan Pangan. 2014;9(1):23-8.

14. Ekawati FI. Hubungan antara keadaan depresi dengan status gizi pada penggguna opiat di pusat rehabilitasi narkoba [Skripsi]. Semarang: Universitas Diponegoro; 2009.

15. Kurniawati DE, Warsini S, Marchira CR. Gambaran skrining keterlibatan penggunaan alkohol, rokok dan zat aditif pada mahasiswa D3 Fakultas Teknik. Berita Kedokteran Masyarakat. 2010;26(2):90.

16. Pantjalina LE, Syafar M, Natsir S. Faktor mempengaruhi perilaku pecandu penyalahgunaan NAPZA Pada masa pemulihan di Rumah Sakit Jiwa Daerah ATMA Husada Mahakam Samarinda [Thesis]. Makassar: Universitas Hasanuddin; 2014.

17. Florence AO, Beatrice O, Okpala PU, Oghale O. Prevalence of drug abuse amongst university students in Benin City, Nigeria. Public Health Research. 2016;6(2):317. doi: 10.5923/j.phr.20160602.01

18. Syarif F, Tafal Z. Karakteristik remaja pengguna narkoba suntik dan perilaku berisiko HIV/AIDS di Kecamatan Ciledug Kota Tangerang. Kesmas: Jurnal Kesehatan Masyarakat Nasional. 2008;3(2):70-5. doi: 10.21109/ kesmas.v3i2.232

19. Shekarchizadeh H, Ekhtiari H, Khami MR, Virtanen JI. Patterns of pre-treatment drug abuse, drug treatment history and characteristics of addicts in methadone maintance treatment in Iran. Harm Reduct J. 2012;9:18. doi: 10.1186/1477-7517-9-18

20. Kementerian Kesehatan RI. Infodatin: Anti narkoba sedunia. [series online] 2017 [cited Januari 2019]. Available from: URL: http://www.depkes.go.id/resources/ download/pusdatin/infodatin/infodatin narkoba 2017.pdf

21. Afiatin T. Pencegahan penyalahgunaan NARKOBA dengan program AJI. Yogyakarta: Gadjah Mada University Press; 2008.

22. Kementerian Kesehatan RI. Angka kecukupan gizi energi, protein yang dianjurkan bagi Bangsa Indonesia. Lampiran Peraturan Menteri Kesehatan Republik Indonesia Nomor 75 Tahun 2013.

23. Hossain KJ, Kamal MM, Ahsan M, Islam SKN. Serum antioxidant micromineral $(\mathrm{Cu}, \mathrm{Zn}, \mathrm{Fe})$ status of drug dependent subjects: influence of illicit drugs and lifestyle. Subst Abuse Treat Prev Policy. 2007;2(12). doi: 10.1186/1747-597X-2-12

24. Nabyl RA. Panduan hidup sehat mencegah dan mengobati diabetes mellitus. Yogyakarta: Aulia Publishing; 2012.

25. Barnes DE. Program olahraga: diabetes (Alih bahasa: Aburiyati). Yogyakarta: PT Citra Aji Parama; 2012.
26. Ernawati F, Rosmalina Y, Permanasari Y. Pengaruh asupan protein ibu hamil dan panjang badan bayi lahir terhadap kejadian stunting pada anak usia 12 bulan di Kabupaten Bogor. Penelitian Gizi dan Makanan. 2013;36(1):1-11.

27. Siahaan G, Nainggolan E, Lestrina D. Hubungan asupan zat gizi dengan trigliserida dan kadar glukosa darah pada vegetarian. Indonesian Journal of Human Nutrition. 2015;2(1):48-59. doi: 10.21776/ub.ijhn.2015.002.01.5

28. Merryana A, Wirjatmadi B. Peranan gizi dalam siklus kehidupan. Jakarta: Kencana; 2014.

29. Fidiani A. Kontribusi zat makro makan siang terhadap status gizi di SDIT Ar. Raihan Tritenggo Bantul Yogyakarta [Skripsi]. Yogyakarta: Universitas Gadjah Mada; 2007.

30. Linder MC. Biokimia nutrisi dan metabolisme. Jakarta: UI Press; 2010.

31. Forrester JE, Tucker KL, Gorbach SL. The effect of drug abuse on body mass index in Hispanics with and without HIV infection. Public Health Nutr. 2005;8(1):61-8. doi: 10.1079/phn2005667

32. Petry M N, Barry D. Associations between body mass index and substance use disorders differ by gender : results from the National Epidemiologic Survey on Alcohol and Related Conditions. Addict Behav. 2009;34(1):51-60. doi: 10.1016/j.addbeh.2008.08.008

33. Tsalissavrina I, Wahono D, Handayani D. Pengaruh pemberian diet tinggi karbohidrat dibandingkan diet tinggi lemak terhadap kadar trigliserida dan HDL darah pada Rattus novergicus Galur Wistar. Jurnal Kedokteran Brawijaya. 2006;22(2):80-9. doi: 10.21776/ ub.jkb.2006.022.02.5

34. Sutiari NK. Konsumsi, status gizi, dan kesehatan masyarakat vegetarian dan non-vegetarian di Bali [Thesis]. Bogor: Institut Pertanian Bogor; 2008.

35. Bawono MN. Kontrol hormon insulin dan glukagon dalam perubahan metabolisme selama latihan. [series online] 2012 [cited Okt 2018]. Avaible from: URL: http:// pelangiilmu.jurnal.unesa.ac.id/bank/jurnal/artikeltugas. (M._Nur_Bawono)-Reeady.pdf

36. Sinaga DMK, Hendra, Righo A. Hubungan antara status merokok dengan indeks massa tubuh pada pria di UPTD Puskesmas Kecamatan Pontianak Kota. Jurnal Proners. 2015;3(1).

37. Mandangi F, Kawengian S, Pangemanan JM. Hubungan konsumsi alkohol dengan status gizi pada pria dewasa usia 30-40 tahun di Desa Kapoya Kecamatan Suluun Tereran Kabupaten Minahasa Selatan [Skripsi]. Manado: FKM Universitas Sam Ratulangi; 2012.

38. Siahaan G. Effectiveness of the provision of snakehead fish nuggets and colored fruit extracts to blood protein (total protein, albumin, $\mathrm{Hb}$ ) in PLHIV. J Phys.: Conf. Ser. 2020;1665:012026. doi: 10.1088/1742-6596/1665/01/2026 